\title{
B-Cell CLL/Lymphoma 9 Protein
}

National Cancer Institute

\section{Source}

National Cancer Institute. B-Cell CLL/Lymphoma 9 Protein. NCI Thesaurus. Code C28707.

B-cell CLL/lymphoma 9 protein (1426 aa, $149 \mathrm{kDa}$ ) is encoded by the human BCL9 gene.

This protein is involved in the modulation of the Wnt signaling pathway. 